\title{
Enhance Effectiveness of Moringa Leaves with Staphylococcus Epidermidis Bacteria
}

\author{
Ali Napiah Nasution \\ Department of Tropical Medicine, Faculty of Medicine, Universitas Prima Indonesia, Medan, Indonesia
}

\section{Abstract}

Plants are a source of various types of medicinal chemical compounds, one of which is as an anti-infection where the use of natural plant-based ingredients (herbs) is again a trend among Indonesians. Cleanliness is very important because of the increasing number of diseases that arise due to bacteria and germs. The skin is the part that covers the surface of the body and has the main function of protecting it from various kinds of disturbances and external stimuli. Moringa leaves are natural ingredients that have antibacterial potential. Moringa (Moringa oleifera, Lamk) is a plant that has antibacterial benefits. Staphylococcus Epidermidis is a bacterium that causes various pyogenic and skin infections, separation, abscess formation, and fatal septicemia. This study aims to test the antibacterial activity of Moringa leaves against Staphylococcus Epidermidis. The method used in the extraction of Moringa leaves is maceration using ethanol as a solvent. As for testing, it is known that the moringa leaf extract has antibacterial activity against Staphylococcus Epidermidis at concentrations of 5\%,10\%, 20\%, 40\%, and $80 \%$ and the minimum inhibitory content (MIC) is $12 \mathrm{~mm}$ in Staphylococcus Epidermidis. The difference in the concentration of Moringa leaf extract influenced the inhibition of the growth of Staphylococcus Epidermidis bacteria.
Keywords

plant Chelsea (Moringa deifera

L); antibacterial activity, inhibition zone measurement

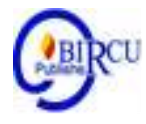

\section{Introduction}

Indonesian people have recognized and used medicinal plants as a countermeasure health problems since time immemorial. Plants are a source of various types of chemical compounds that have properties as medicine. Utilization of plants as medicine is inherited from our ancestors who have been since time immemorial and have been many used for a sufficient period long time almost all over the world (Djauhariya and Hernani, 2004).

The latest research from WHO in 2013 states that washing hands can prevent and remove germs from $92 \%$ of the organisms that cause infection in the hands. According to Triatmodjo's (1993) study, it was found that $34.4 \%$ of nurses' hands were contaminated with germs that cause nosocomial infections and $34.4 \%$ of non-sterile surgical instruments. The most common infections are caused by Staphylococcus epidermidis bacteria. These bacteria are gram-positive bacteria, often in the body of healthy people on the skin and mucosa, $20-75 \%$ are found in the upper respiratory tract, face, hands, hair, and vagina. Therefore, it is very important to maintain cleanliness, one of which is frequent hand washing. 
Cleanliness is very important because of the increasing number of diseases that arise due to bacteria and germs. The skin is the part that covers the surface of the body and has the main function of protecting it from various kinds of disturbances and external stimuli. If the skin is no longer intact (injured), it becomes a door for the entry of microorganisms or germs that cause infection. Infection is caused by a microorganism, namely the Staphylococcus epidermidis bacteria. One of the simplest and most common ways to keep skin clean is to take a shower with soap. Soap is a mixture of sodium compounds and fatty acids that are used as body cleansing agents, in the form of solids, foam, with or without other additives, and does not irritate the skin (BSN, 1994). Carolyne T, et al (2021) stated that skin disease is a disease related to the environment and human behavior. In Indonesia, skin disease is still a public health problem. The causes of skin diseases also vary widely, ranging from viruses, germs, fungi and parasites.

Development of medicinal plant production increasingly rapidly, influenced by consciousness a society that is rising about the benefits medicinal plants (Dalimartha, 1999). The public is increasingly aware of its importance back to nature by utilizing medicine - natural medicine. This is caused by the use of drugs derived from ingredients nature has relatively side effects smaller (Djauhariya and Hernani, 2004). Moringa plant has been used to combat malnutrition especially in developing countries on the African peninsula, are often used as vegetables, especially for agriculture and reproduce breast milk. Moringa leaves are also efficacious as a hepatoprotection, and moringa contains antioxidants high and good for diseases related to digestion (Putri, 2011).

The results of this study are expected to be useful for development of science in utilization Moringa oleifera, Lamk as an antibacterial for improvement public health services, especially in the field traditional medicine especially against infectious diseases where it is vulnerable the entry of microorganisms into the body, then breed and cause disease (Dwidjoseputro, 1994).

Staphylococcus Epidermidis bacteria are normal bacteria in the mouth and ducts exhalation but in no state pathogenic causes infection of the skin (Jawetz et al, 2001). Based on the description above. Researchers are interested to research activities Antibacterial Moringa Leaf Extract (Moringa oleifera L.) against Staphylococcus Epidermidis. Also in the future, it can be a source of information to the community about the use of the Moringa plant oleifera, Lamk as an antibacterial agent for Staphylococcus Epidermidis.

Research on natural ingredients themselves has been widely researched in Indonesia. This related to the active ingredient content as a result of secondary metabolism on plants that can give a lot benefits, one of which is found in moringa plant which has the anti function cancer, anti-bacterial, hypotensive, inhibitor the activity of bacteria and fungi (Anwar et al., 2007). This is related to the content The chemical contained in it is rich will vitamin A and vitamin C, compounds locomotion and isothiocyanate (Bharali, 2003).

\section{Research Methods}

Test bacteria used in the research stage is Staphylococcus Epidermidis. These bacteria are acquired from the Microbiology Laboratory of UNPRI Medan. North Sumatera The medium used in the research stage this is the Brain Heart Infusion (BHI) medium, Vogel Johnson Agar (VJA), Mueller Hinton Agar (MHA), serum or plasma. The chemicals used in this study is sterile aqua dest, Standard Solution Brown II, ethanol 70\%, $\mathrm{Mg}$ powder, alcohol solution: $\mathrm{HCl}$ (1: 1), amyl solvent alcohol, Mayer's solution, Dragendrof reagent, iron reagent (III) chloride, $\mathrm{HCl} 2 \mathrm{~N}$. 
The tools used in this research include: blender, filter, milligram balance, sieve number 100, test tube, measuring cup, stirring rod, Erlenmeyer, beaker glass, maceration tool, petri dish, loop needle, boor prop, sterile cotton swab, sterile tweezers, clinic pet, vaporizer cup, oven, autoclave, Incas septic box, incubator, separator funnel. then Moringa leaf powder weighs 200 grams, then transferred into a dark bottle which adds $1500 \mathrm{ml}$ of $70 \%$ ethanol by comparison (1:75), then stirred and closed. After that let stands for 5 days. In the process of immersion shaking is done at least 3 times a day. A result from the immersion process filtered then concentrated by putting it in the oven. The concentrated extract is put in a sterile container (Voight, 1994).

Test bacteria that have been inoculated taken with a sterile loop wire then suspended into a tube containing $2 \mathrm{ml}$ of $0.9 \% \mathrm{NaCl}$ solution until obtained turbidity equal to the standard the turbidity of the Mc solution. Farland. Treatment the same is done with each type test bacteria.

The test media was made using the method diffusion of agar by pouring NA $10 \mathrm{~mL}$ into 6 petri dishes for coating base after the first layer solidifies, on the surface of the substrate is laid 7 adjusted wells in such a spaced order that the area observers don't grow with each other, then the bacterial suspension is mixed in hatchery media NA, after that in pour $25 \mathrm{~mL}$ NA on each petri dish for the second layer. Next is the backup is lifted aseptically from a petri dish, so that a well is formed which will be used in the antibacterial testing.

\section{Results and Discussion}

\subsection{Phytochemical Screening}

Phytochemical screening is one way to determine the secondary metabolite content of a plant sample. The results of the phytochemical screening of the ethanol extract of Moringa leaves, bidara leaves and Dewa Crown leaves can be seen in the following table:

Table 1. Results of Moringa Leaf Phytochemical Screening

\begin{tabular}{|c|c|c|c|c|}
\hline $\mathrm{No}$ & Compound Group & Name Reagent & Color formed & Result \\
\hline \multirow[t]{3}{*}{1} & \multirow[t]{3}{*}{ Alcholoid } & Meyer & End. White & + \\
\hline & & Dragendroff & End. Yellow orange & + \\
\hline & & Bouchart & End. Red Brown & + \\
\hline 2 & Tannins & $\begin{array}{l}\text { Hot water }+ \\
\mathrm{FeCl} 310 \%\end{array}$ & Bluish Green & + \\
\hline 3 & Saponins & $\begin{array}{l}\text { Hot water + HCL } \\
2 \mathrm{~N}\end{array}$ & Formed a stable foam & + \\
\hline 4 & Flavonoids & $\begin{array}{l}\text { Concentrated } \\
\mathrm{HCL}+\mathrm{Mg} \\
\text { powder }\end{array}$ & Brownish yellow & - \\
\hline 5 & Triterpene / steroids & & Purple red & $\begin{array}{l}+ \\
+\end{array}$ \\
\hline 6 & Glycosides Sugar & $\begin{array}{l}\text { Lieberman - } \\
\text { burchat }\end{array}$ & & - \\
\hline 7 & Non Sugar Glycosides & LP molish & Bluish green & - \\
\hline 8 & $\begin{array}{l}\text { Anthraquinone } \\
\text { Glycosides }\end{array}$ & $\begin{array}{l}\text { Lieberman } \\
\text { Burchad }\end{array}$ & $\begin{array}{l}\text { No purple rings were } \\
\text { formed }\end{array}$ & - \\
\hline 9 & Polyphenols & $\begin{array}{l}\mathrm{CCl} 4+\text { dilute } \\
\text { ammonia }\end{array}$ & Greenish yellow & + \\
\hline
\end{tabular}


Based on the table above, shows that the results of phytochemical screening on Moringa leaves have positive compound groups in alkaloids, tannins, saponins, triterpene/steroids, and polyphenols. Meanwhile, negative results on phytochemical screening were found in the class of flavonoids, sugar glycosides, non-sugar glycosides, and anthraquinone glycosides.

\subsection{Zone of Obstacle}

\section{a. Staphylococcus Epidermidis}

Through the effectiveness test of Moringa leaf extract, an inhibition zone (clear zone) was produced around the disc paper that had been dripped with several concentrations. Then the measurement is done using a caliper by measuring the area of the drag zone in the vertical or horizontal part in the clear area around the disc. Do special same for each treatment and calculate the average. As shown in the picture and table below:

Table 2. Inhibition Zone Results of Moringa Oleifera Leaf Extract Against

\begin{tabular}{cccc} 
& \multicolumn{3}{c}{ Staphylococcus Epidermidis } \\
\hline Concentration & \multicolumn{3}{c}{$\%$ Clear Zone Diameter $(\mathbf{m m})$ Moringa Leaves } \\
\cline { 2 - 4 }$\%$ & \multicolumn{3}{c}{ Staphylococcus Epidermidis } \\
& U1 & U2 & Averages \\
$0 \%$ & $\mathbf{9 , 0}$ & $\mathbf{9 , 3}$ & $\mathbf{9 , 1 5}$ \\
$2,5 \%$ & 10,0 & 10,4 & 10,2 \\
$5 \%$ & 11,0 & 11,1 & 11,05 \\
$7,5 \%$ & 12,3 & 12,3 & 12,3 \\
K+ & 25 & 25,8 & 26,9 \\
\hline
\end{tabular}

Based on the table above, shows that the results of research using Moringa Oleifera leaf extract were given different results. At a concentration of $0 \%$, it has an average of 9.15 $\mathrm{mm}$, at a concentration of $2.5 \%$ it has an average of $10.2 \mathrm{~mm}$, at a concentration of $5 \%$ it has an average of $11.05 \mathrm{~mm}$, and at a concentration of $7.5 \%$ it has an average of - average $12.3 \mathrm{~mm}$.

The lowest inhibition zone diameter was $0 \%$ in the first experiment which was 9.0 $\mathrm{mm}$ and the highest inhibition zone diameter was $7.5 \%$ in the second experiment which was $12.3 \mathrm{~mm}$. The positive control used was Chloramphenicol with an inhibition zone of 26.9 $\mathrm{mm}$. This shows that the higher the concentration of Moringa leaf extract, the greater the effectiveness as an anti-bacterial in Staphylococcus Epidermidis as evidenced by the area of the inhibition zone.

The treatment given by Chloramphenicol against Staphylococcus Epidermidis bacteria got different results. Chloramphenicol found the highest inhibition zone was in the second treatment, namely $25.8 \mathrm{~mm}$. Where Chloramphenicol functions as a positive control of the test substance (Moringa leaf extract). 
b. Comparison of Inhibition Zone of Moringa Oleifera Leaf Extract and Chloramphenicol against Staphylococcus Epidermidis

By comparing the results of the inhibition zone of Moringa leaf extract and chloramphenicol, it was found that:

Ha: There is a difference in effectiveness between Moringa leaves and chloramphenicol against Staphylococcus Epidermidis bacteria

H0: There is no difference in effectiveness between Moringa leaves and chloramphenicol against Staphylococcus Epidermidis bacteria.

And through the One Way Anova test, it was found that the value of $\mathrm{P}=0.000$, which means $\mathrm{p}<\alpha$ where $\alpha<0.05$, then $\mathrm{Ha}$ is accepted and $\mathrm{H} 0$ is rejected, so there is a difference in the effectiveness of Moringa leaf extract and chloramphenicol.

This research test using One Way Anova with homogeneous and normal data requirements. Where in the normality test the Sigma $(\mathrm{P})$ value is more than 0.05 , namely 0.203 , the data is normally distributed. And through the One Way Anova test, it was found that the value of $\mathrm{P}=0.000$, which means $\mathrm{p}<\alpha$ where $\alpha<0.05$, then Ha is accepted because there is a difference and $\mathrm{HO}$ is rejected because there is no difference, so there is a difference in the effectiveness of Moringa leaf extract and chloramphenicol.

Followed by the Post Hoc Turkey Test, which shows that from the results of the Turkey analysis there are different results from each treatment with a confidence index of 95\% and HSD. From the Post Hoc Turkey test, it is also known that the treatment of Moringa leaf extract against Staphylococcus Epidermidis bacteria is the effectiveness above compared to the bidara leaf extract with the control concentration (chloramphenicol).

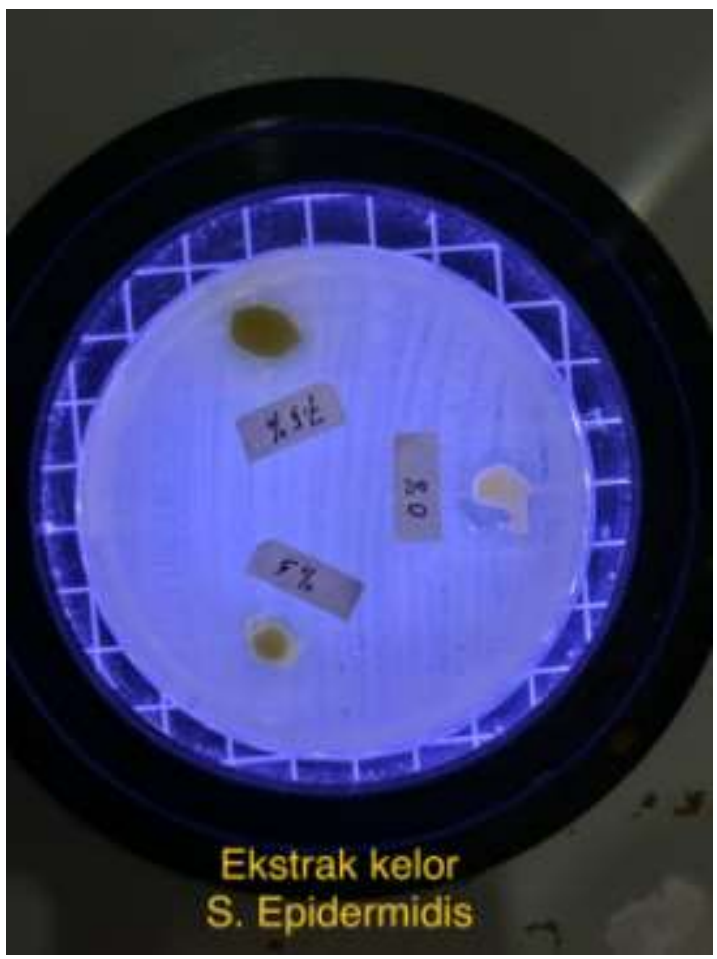

Figure 1. change to extract 


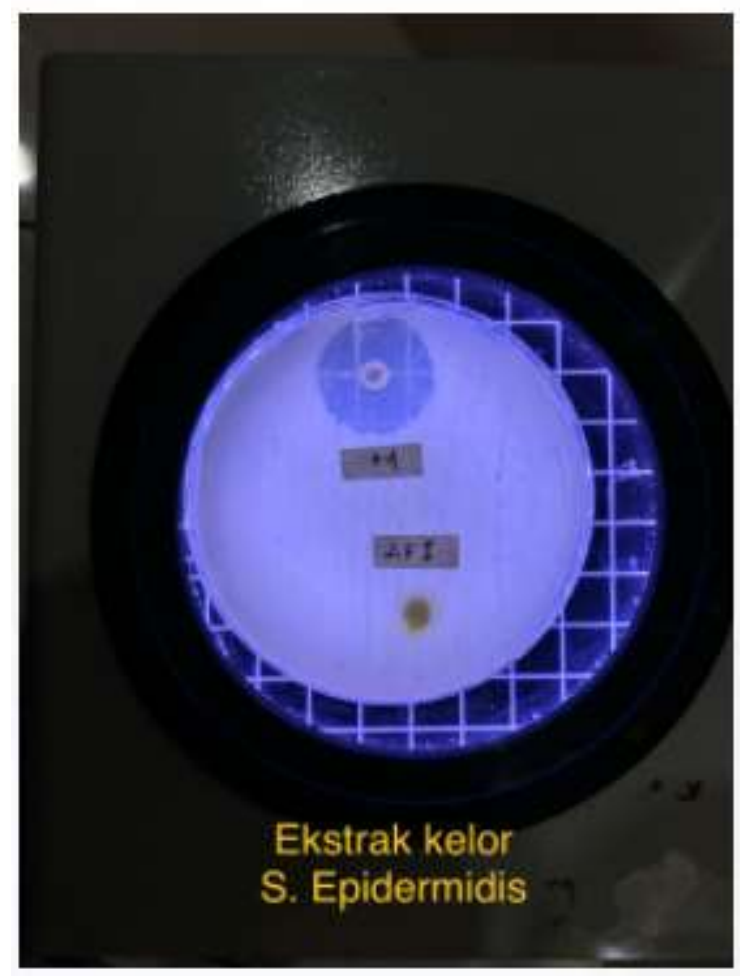

Figures 2. The extract change pattern

\subsection{Discussion}

Based on the results of the research data, it was found that the effectiveness of Moringa Oleifera (Moringa Oleifera) and Chloramphenicol leaf extracts on the growth of Staphylococcus Epidermidis bacteria also showed differences in the effectiveness of each of these extracts. The effectiveness that arises is the presence of a zone of inhibition or a clear zone around the disc paper.

The method chosen for testing the effectiveness of this antimicrobial is the disc diffusion method. Where this method is the method most often used to determine the effectiveness of antimicrobials. It works by observing the clear area, which indicates an inhibition of the growth of microorganisms by antimicrobials on the surface of the agar medium. The formation of the inhibition zone is due to the prevention or inhibition of the growth of microorganisms around the disc containing the extract. The formed inhibition zone is measured using the calipers to determine the effectiveness of the treatment.

Through the One Way Anova statistical test on the Staphylococcus Epidermidis bacteria, it was found that the value of $\mathrm{P}=0.000$ which means $\mathrm{p}<\alpha$ where $\alpha<0.05$, then Ha is accepted and $\mathrm{HO}$ is rejected, so there is a difference in the effectiveness of Moringa leaf extract and chloramphenicol. This research test using One Way Anova with homogeneous and normal data requirements. And through the One Way Anova test, it was found that the value of $\mathrm{P}=0.000$, which means $\mathrm{p}<\alpha$ where $\alpha<0.05$, then $\mathrm{Ha}$ is accepted because there is a difference and $\mathrm{H} 0$ is rejected because there is no difference, so there is a difference in the effectiveness of Moringa leaf extract and chloramphenicol.

Followed by the Post Hoc Turkey Test, which shows that from the results of the Turkey analysis there are different results from each treatment with a confidence index of 95\% and HSD. From the Post Hoc Turkey test, it is also known that the effectiveness of the 
treatment of Moringa leaf extract against Staphylococcus Epidermidis bacteria was compared to the control concentration (chloramphenicol).

This research test using One Way Anova with homogeneous and normal data requirements. Where in the normality test the Sigma $(\mathrm{P})$ value is more than 0.05 , namely 0.199 , the data is normally distributed. And through the One Way Anova test, it was found that the value of $\mathrm{P}=0.000$, which means $\mathrm{p}<\alpha$ where $\alpha<0.05$, then Ha is accepted because there is a difference and $\mathrm{HO}$ is rejected because there is no difference, so there is a difference in the effectiveness of Moringa leaf extract and chloramphenicol.

The results of this study are also in accordance with the results of research by Edi Suriaman (2017) and Shalikhatul Khasanah (2012) which states that Moringa leaf extract can inhibit the growth of Staphylococcus Epidermidis bacteria and can be used as antibacterial.

\section{Conclusion}

The conclusions from the results of this study are as follows:

1. Moringa leaf extract and Chloramphenicol have effectiveness in inhibiting the growth of Staphylococcus Epidermidis.

2. Based on the inhibition zone classification, Moringa leaves have the best inhibitory effect against the growth of Staphylococcus Epidermidis bacteria.

3. In the control concentration, Moringa leaf extract was the most effective at inhibiting the growth of Staphylococcus Epidermidis bacteria.

\section{References}

Aditya Nugraha. 2013. Bioaktivitas (Moringa oleifera) Terhadap Eschericia coli Penyebab Kolibasilosis Pada Babi. UDAYA. Denpasar.

Anonim. 1986. Sediaan Galenik. Departemen Kesehatan RI, Jakarta.

Anwar, F., Latif, S., Ashraf, M., Gilani, A.H., 2007. Moringa oleifera: A Food Plant with Multiple Medical Uses

Ali Napiah Nasution, 2020, Uji Metabolit Sekunder Metode Kualitatif Pada Daun Kelor (Moringa Oleifera), Daun Bidara (Ziziphus Mauritiana) Dan Daun Mahkota Dewa (Phaleria Macrocarpa), ejournal Unaja.

Carolyne T. R.N., et al. (2021). Relationship between Knowledge, Clothing Cleanliness, Towel Cleanliness and Environmental Sanitation with Scabies Incidents at the Pekanbaru City Child Special Development Institute (LPKA) in 2019. Budapest International Research and Critics Institute-Journal (BIRCI-Journal), P. 122-130.

Dalimartha, S. 1999. Atlas Tumbuhan Obat Indonesia. Jilid 1.Trubus Agriwidya, Jakarta.

Djauhariya, E., Hernani. 2004. Gulma Berkhasiat Obat. Penerbit Swadaya. Jakarta

Jawetz E., Melnick GE., Adelberg CA. 2001. Mikrobiologi Kedokteran. Edisi I. Penerjemah: Bagian Mikrobiologi Kedokteran Universitas Airlangga. Penerbit Salemba Medika, Surabaya. Halaman 211-249. [8]Jawetz E., Melnick GE., Adelberg CA .2007. Mikrobiologi Kedokteran. Edisi 23. Selamba Medika, Surabaya.

Lay, B. W. 1994. Analisis Mikroba di Laboratorium. Edisi 1. Raja Grafindo Persada, Jakarta.I Pandey, A., R.D. Pandey., P. Tripathi., P.P. Gupta., J. Haider., S. Bhatt ., A.V Singh. 2012. Moringa oleifera Lam. (Sahijan) - A Plant with Plethora of Diverse Therapeutic Benefits: An Updated Resrospection. Pandeyet al. Medical Aromatic Plants 2012. Robinson, T. 1995. Kandungan Organik Tumbuhan Tinggi, cetakan VI (terjemahan). Penerbit ITB. Bandung. Hal 367. Setiabudy, R. 2007. 
Antimikroba : Dalam Farmakologi dan Terapi. Edisi V (Cetak Ulang Dengan Perbaikan. 2008). Balai Penerbit FKUI. Jakarta. Vandepitte., J.Engbaek. K., Rohmar. P., Pint. P., Heuck. C.G. 2005. Prosedur laboratorium Dasar dan untuk Bakteriologis Klinis. Edisi 2.Buku Kedokteran EGC. Jakarta.

Victor, L. 1980. Antibiotics in Laboratory Test. The Williams and Wilkins Company, USA.

Vinoth, B., Manivasagaperumal, R., Balamurungan, S., 2012. Phytochemical Analysis and Antibacterial Activity of Moringa Oleifera Lam. International Journal of Research in Biological Sciences 2012; 2(3): 98-102. 